\title{
Accurate breast cancer diagnosis through real-time PCR her-2 gene quantification using immunohistochemically-identified biopsies
}

\author{
GRETEL MENDOZA $^{1}$, AMELIA PORTILLO ${ }^{2}$ and JORGE OLMOS-SOTO ${ }^{1}$ \\ ${ }^{1}$ Molecular Microbiology Laboratory, Department of Marine Biotechnology, \\ Center for Scientific Research and Education (CICESE); \\ ${ }^{2}$ Science Faculty, Autonomous University of Baja California (UABC), Ensenada, Baja California 22860, Mexico
}

Received July 3, 2012; Accepted October 1, 2012

DOI: 10.3892/ol.2012.984

\begin{abstract}
. her-2 gene amplification and its overexpression in breast cancer cells is directly associated with aggressive clinical behavior. The her-2 gene and its Her-2 protein have been utilized for disease diagnosis and as a predictive marker for treatment response to the antibody herceptin. Fluorescent in situ hybridization (FISH) and immunohistochemistry (IHC) are the most common FDA-approved methodologies involving gene and protein quantification, respectively. False positive or negative her-2/Her-2 patient results may result in inappropriate treatment administration. To support accurate quantification and interpretation of results, in this study we have standardized qPCR analysis using previously identified IHC samples, obtaining very significant and clinically useful results.
\end{abstract}

\section{Introduction}

Breast cancer (BC) is one of the most common causes of mortality among females, accounting for $23 \%$ of total cancer cases and $14 \%$ of cancer mortality around the world (WHO, 2010). Lately, the number of BC fatalities has increased approximately to 40,000 annually in Mexico (http://www. sinais.salud.gob.mx/estadisticasportema.html). In human cancer, oncogenes such as her-2 have been identified and used as molecular markers. her-2 is one of the most frequently studied BC genes due to its overexpression observed in $20-30 \%$ of aggressive cases. High levels of her-2 have also been found in several ovarian and endometrial tumors (1). Clinical studies have shown that her-2 gene upregulation and Her-2 protein overproduction predicts poor prognosis in $\mathrm{BC}$

Correspondence to: Professor Jorge Olmos-Soto, Molecular Microbiology Laboratory, Department of Marine Biotechnology, Center for Scientific Research and Education (CICESE), Ensenada, Baja California 22860, Mexico

E-mail: jolmos@cicese.mx

Key words: breast cancer, her-2/Her-2, immunohistochemistry, quantitative polymerase chain reaction patients lacking estrogen and progesterone receptors, inducing a high rate of cell proliferation and tumor chemotherapy resistance $(2,3)$. The discovery of her-2 gene overexpression in $\mathrm{BC}$ tissues and its association with aggressive clinical behavior has generated diagnostic interest by using her-2 gene expression as a predictive marker for herceptin treatment response (1-3). Immunohistochemistry (IHC) is the first methodology selected for Her-2 protein evaluation since it is the most economical; however, it is not the most precise. Females with an IHC score 3+ are candidates for the costly herceptin treatment. Samples with IHC score of $2+$ are considered as inconclusive and a second evaluation with fluorescent in situ hybridization (FISH) methodology is required. FISH analysis is frequently omitted due to its high cost, the time-consuming methods involved and the shortage of specialized laboratories in which to perform it. The lack of a rapid, precise and economical her-2/Her-2 diagnostic test makes it necessary to implement alternative methodologies that have a lower cost, are less time-consuming and are more precise. In this study we standardize a quantitative polymerase chain reaction (qPCR) methodology that satisfies all premises mentioned before; being less expensive and less time-consuming than FISH and more precise than IHC.

\section{Materials and methods}

Tissue sample preparation and DNA biopsy extraction. Twenty-six biopsies of $\mathrm{BC}$ tissue fixed in formaldehyde and embedded in paraffin were previously analyzed by IHC. Eight of these samples were evaluated as IHC $3+$, fifteen were evaluated as IHC $2+$ and three of them were negative for Her-2 using the same methodology. All samples came from a private laboratory of clinical pathology in Ensenada (Baja California, Mexico). Biopsies were collected between 2004 and 2008 and stored at room temperature. Block samples were cut into $10-\mu \mathrm{m}$-thick sections and transferred into a sterile 1.7-ml tube. Paraffin was removed twice using $1 \mathrm{ml}$ xylene for a $10 \mathrm{~min}$ incubation period and washed using $1 \mathrm{ml}$ absolute ethanol, $1 \mathrm{ml}$ $90 \%$ ethanol and $1 \mathrm{ml} 70 \%$ ethanol, followed by $1 \mathrm{ml} \mathrm{TE}$ buffer. Tissues were pelleted following each step by centrifugation at $8,000 \mathrm{x}$ g for $5 \mathrm{~min}$. Final pellets were treated with $390 \mu \mathrm{l}$ lysis 


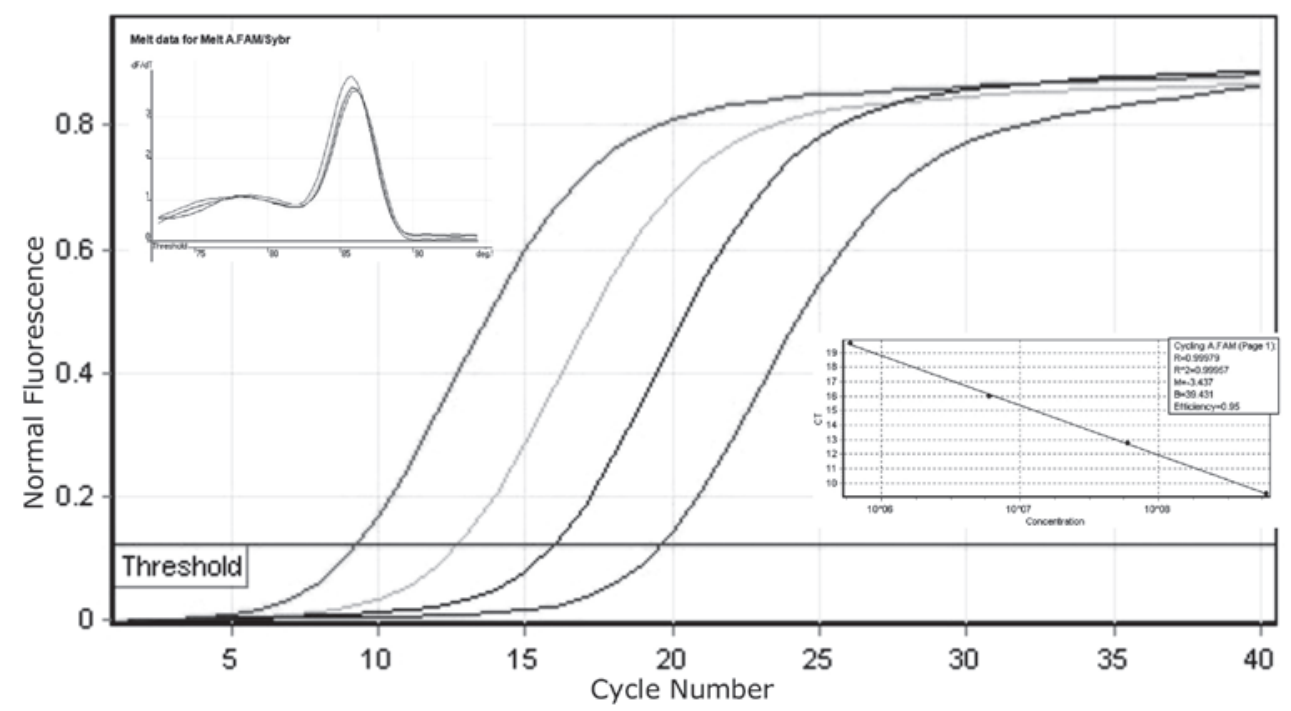

Figure 1. Plasmid dilutions presenting a strong correlation in her-2 qPCR curve standardization. Correlation coefficient was $>0.999$ and the melting curves of her-2 are shown as a single, sharp, narrow peak, indicating pure and homogeneous qPCR products were obtained. Similar results were obtained with whn gene control curve standardization (data not shown). qPCR, quantitative polymerase chain reaction.

buffer [150 mM NaCl, 15 mM EDTA, $60 \mathrm{mM}$ Tris, (pH 8.0)], $50 \mu 110 \%$ SDS, $25 \mu 1$ lysozyme at $10 \mathrm{mg} / \mathrm{ml}, 10 \mu 1 \mathrm{RNase}$ at $10 \mathrm{mg} / \mathrm{ml}$ and incubated at $37^{\circ} \mathrm{C}$ for $30 \mathrm{~min}$. Proteinase $\mathrm{K}$ digestion was carried out overnight out using $1 \mathrm{mg} / \mathrm{ml}$ of the enzyme at $37^{\circ} \mathrm{C}$ (4). Chromosomal DNA was extracted by the standard protocol of phenol/chloroform/isoamyl alcohol and stored at $-20^{\circ} \mathrm{C}$ until use. Quantification of DNA molecules extracted from paraffin-embedded tissue samples was estimated by spectrophotometer at $260 \mathrm{~nm}$ (5).

The study was approved by the ethics committee of the Center for Scientific Research and Education (CICESE), Ensenada, Baja California, Mexico.

Control curve standardization. PCR products from her-2 (103 bp) and winged helix nude (whn; $93 \mathrm{bp)} \mathrm{control} \mathrm{gene} \mathrm{were}$ obtained using fresh placental-extracted DNA and her-2-F, 5'-AAC TGG TGT ATG CAG ATT GC-3' and her-2-R, 5'-AGC AAG AGT CCC CAT CCT A-3'; whn-F, 5'-GGT GGA ATG ACC GAA GCT AT-3' and whn-R, 5'-GTC CTT CTG TGG CTC AAT CT-3'; primers previously published $(6,7)$. PCR products were cloned using a pGEM vector (Promega ${ }^{\circledR}$; Madison, WI, USA) and positive clones were grown in LB broth medium with $50 \mu \mathrm{g} / \mathrm{ml}$ ampicillin. Plasmid DNA was purified using Qiagen ${ }^{\circledR}$ miniprep kit (Hilden, Germany) and its concentration was measured by spectrophotometry assuming $1 \mathrm{OD}$ at $260 \mathrm{~nm}=50 \mu \mathrm{g} / \mathrm{ml}$ DNA (5). Serial dilutions from $10^{10}-10^{5}$ molecules were prepared. Dilutions were used as plasmid copy number standards to generate a control curve and to quantify paraffin extracted her- 2 chromosomal DNA copies (Fig. 1). General formula used: $\left(6.02 \times 10^{23} \mathrm{copies} / \mathrm{mol}\right)$ $\mathrm{x}($ concentration in $\mathrm{g} / \mu \mathrm{l}) /(\mathrm{MW}$ in $\mathrm{g} / \mathrm{mol})=$ copies $/ \mu \mathrm{l}$.

qPCR experimental conditions. Primers were obtained from Allele Biotech (San Diego, CA, USA). For amplification and data collection we used the Rotor-Gene 2000 real time cycler and software (Corbett Research; Sydney, Australia). Reactions were carried out in triplicate in a total volume of $25 \mu \mathrm{l}$. Each reaction mixture contained 1X PCR mix Rotor-Gene SYBR-Green, Qiagen ${ }^{\circledR}$; 4 ng of each primer and $87 \mathrm{ng}$ of template DNA final concentration. Cycling conditions were $95^{\circ} \mathrm{C}$ for $5 \mathrm{~min}, 40$ cycles; at $95^{\circ} \mathrm{C}$ for $20 \mathrm{sec}$; at $60^{\circ} \mathrm{C}$ for $20 \mathrm{sec}$ and at $72^{\circ} \mathrm{C}$ for $20 \mathrm{sec}$. Standard curves were prepared using $5 \mu 1$ of each plasmid dilution and $20 \mathrm{ng}$ of each primer.

qPCR her-2 gene quantification. her- 2 gene quantification in negative and positive (IHC 2+, IHC 3+) patient samples were obtained by calculating the ratio between her-2/whn gene amplification parameters. According to commercial protocols her $2 / w h n$ negative control must present a value $<2.0$. Patient sample ratios with $<2.0$ values were also regarded as negative for her-2 amplification. Patient sample ratios with $>2.0$ values were regarded as positive for her-2 gene amplification.

\section{Results and Discussion}

Twenty-six BC biopsies previously evaluated by IHC were analyzed using a qPCR methodology. Biopsies 49, 50 and 51 , reported as negative in IHC evaluation, also presented negative results in the qPCR analysis developed in this study (Table I). Fifteen biopsies were evaluated as IHC $2+$ and eight were evaluated as IHC $3+$ for Her-2 protein production (Table I). Biopsies 11 and 29 that were previously evaluated as IHC $3+$ presented a $<2.0$ qPCR ratio in our evaluation. This result is considered as her-2 negative when using commercial kits (e.g., her-2/neu DNA Quantification Assay; Roche Molecular Biochemicals, Mannheim, Germany). In this sense, samples 11 and 29 possibly demonstrated a polysomic condition because high qPCR values were obtained by her-2 and whn genes individually (data not shown). In other words, the whn reference gene is located on the same chromosome as the her-2 gene, therefore in a polysomic condition the her-2/whn ratio will always be around the value of 1.0 (Table I). It has been reported by FISH that her-2 gene amplification occurs 
Table I. qPCR results from formalin-fixed and paraffin-embedded breast biopsies tumors.

\begin{tabular}{|c|c|c|c|c|c|c|c|}
\hline ID & Year & $\begin{array}{c}\text { Patient age } \\
\text { (years) }\end{array}$ & IHC & Lowest qPCR ratio & Highest qPCR ratio & Average ratio & SD \\
\hline 1 & 2004 & 72 & $3+$ & 10.87 & 11.98 & 11.43 & 0.78 \\
\hline 6 & 2004 & 47 & $3+$ & 10.34 & 10.51 & 10.43 & 0.12 \\
\hline 11 & 2004 & 44 & $3+$ & 0.90 & 1.19 & 1.05 & 0.21 \\
\hline 14 & 2005 & 55 & $3+$ & 3.46 & 4.00 & 3.73 & 0.38 \\
\hline 19 & 2005 & 59 & $3+$ & 9.02 & 10.24 & 9.63 & 0.86 \\
\hline 29 & 2005 & 75 & $3+$ & 1.91 & 1.86 & 1.89 & 0.04 \\
\hline 31 & 2005 & 35 & $3+$ & 7.29 & 8.24 & 7.77 & 0.67 \\
\hline 64 & 2008 & 54 & $3+$ & 10.04 & 9.95 & 10.00 & 0.06 \\
\hline 3 & 2004 & 58 & $2+$ & 1.01 & 1.49 & 1.25 & 0.34 \\
\hline 5 & 2004 & 53 & $2+$ & 3.19 & 3.64 & 3.42 & 0.32 \\
\hline 7 & 2004 & 46 & $2+$ & 1.44 & 1.20 & 1.32 & 0.17 \\
\hline 8 & 2004 & 51 & $2+$ & 5.24 & 4.96 & 5.10 & 0.20 \\
\hline 25 & 2005 & 47 & $2+$ & 4.50 & 3.80 & 4.15 & 0.49 \\
\hline 35 & 2005 & 45 & $2+$ & 7.11 & 4.37 & 5.74 & 1.94 \\
\hline 65 & 2008 & 50 & $2+$ & 1.54 & 1.70 & 1.62 & 0.11 \\
\hline 68 & 2009 & 35 & $2+$ & 3.96 & 3.64 & 3.80 & 0.23 \\
\hline 70 & 2009 & 57 & $2+$ & 3.33 & 2.70 & 3.02 & 0.45 \\
\hline 71 & 2007 & 90 & $2+$ & 2.42 & 3.41 & 2.92 & 0.70 \\
\hline 73 & 2008 & 38 & $2+$ & 3.82 & 2.78 & 3.30 & 0.74 \\
\hline 74 & 2008 & - & $2+$ & 9.80 & 9.85 & 9.83 & 0.04 \\
\hline 75 & 2008 & 50 & $2+$ & 3.35 & 3.49 & 3.42 & 0.10 \\
\hline 77 & 2008 & 73 & $2+$ & 1.59 & 1.58 & 1.59 & 0.01 \\
\hline 78 & 2008 & 52 & $2+$ & 50.40 & 52.49 & 51.45 & 1.48 \\
\hline 49 & 2006 & 55 & neg & 1.14 & 1.42 & 1.28 & 0.20 \\
\hline 50 & 2006 & 56 & neg & 0.50 & 0.61 & 0.56 & 0.08 \\
\hline 51 & 2006 & 80 & neg & 1.00 & 0.62 & 0.81 & 0.27 \\
\hline Control & & & & 0.92 & 1.08 & 1.00 & 0.11 \\
\hline
\end{tabular}

IHC, immunohistochemistry; qPCR, quantitative polymerase chain reaction; SD, standard deviation.

on its own chromosome or have chromosome 17 polysomy, the latter being always reported as negative by qPCR (8). In addition, FISH analysis depends on the number of her-2 positive cells observed with respect to the amount of tissue analyzed. In this sense, qPCR analysis avoids this possible misinterpretation during ratio calculation among her-2/whn genes as independent from tissue amounts.

In the IHC $3+$ samples, sample 14 presented a 3.73 average qPCR ratio. Most of IHC $2+$ biopsies evaluated in this study and reported in Table I, presented a similar 3.5 average qPCR ratio, meaning that biopsy 14 should be considered as an IHC 2+ and not an IHC 3+ sample. In addition, IHC 3+ samples 1, 6, 19, 31 and 64 presented a 9.5 qPCR average ratio, making these results most reasonable for an IHC $3+$ evaluation performed by a pathology laboratory (Table I).

Previous studies have shown an equivalence of $80-90 \%$ among FISH and qPCR techniques on samples assessed as $3+$ by IHC $(9,10)$. In this sense, our results confirm the same percentage of accuracy, as we only had one discrepancy among the eight samples analyzed (ID 14). The discrepancies in samples 11 and 29 were caused by polysomy of the her- 2 gene on chromosome 17, not IHC or qPCR misevaluation. However, special attention must be given to polysomy when qPCR is the only methodology utilized. Generally, high qPCR values will be found for her-2 and whn genes individually, contrary to low qPCR values obtained in negative or IHC 2+ samples.

Conversely, great differences have been reported between IHC $2+$ results with respect to FISH and qPCR evaluations (9-11). It has been mentioned that IHC 2+ result variability is principally caused by tissue quality, fixation time, type of antibody used and lack of standardization among users $(3,12)$. In this sense, our experience indicates that IHC $2+$ misevaluation depends on low Her-2 protein levels contained in samples analyzed, but principally on resolution capacity limitations of IHC methodology to quantify low target protein levels. It is important to consider that IHC 3+ sample biopsies were also evaluated by the same pathology laboratory and few discrepancies were obtained.

Discrepancies of 20-40\% from samples evaluated as IHC $2+$ with respect to results obtained by using FISH or qPCR techniques have been reported (11,13-17). In this study, from fifteen biopsies evaluated as IHC 2+, four (ID 3, 7, 65 
and 77) were identified with a $<2.0$ qPCR ratio, showing non-amplification differences with respect to the negative control (Table I). In addition, some researchers have suggested that qPCR cut-off should be greater than 2.7 to be considered as her-2 amplification $(11,16,18)$. In this sense, we suggest that qPCR ratios between 2.5 and 5.0 must be considered as an IHC $2+$ result. In this study, almost $50 \%$ of IHC $2+$ biopsies analyzed presented a 3.5 average qPCR ratio that adequately matched our proposal. However, samples 8, 35, 74 and 78, also reported as IHC $2+$, presented a $>5$ qPCR ratio, meaning that these samples must be classified as IHC $3+$ instead of IHC 2+. In this case, a misevaluation occurred when using IHC methodology with respect to GPCR, even when these biopsies presented high Her-2 protein levels. Taking into account samples $8,35,74$ and 78 , presenting a $>5$ qPCR ratio, and samples 3, 7, 65 and 77, presenting a $<2$ qPCR ratio, more than $50 \%$ of biopsies identified as IHC $2+$ were wrongly classified, displaying a higher percentage discrepancy with respect to data reported $(3,11,13,16)$. The results obtained in this study suggest a new IHC-qPCR relationship, which could be used to easily differentiate among IHC negative, IHC 2+ and IHC 3+ results. IHC negative result samples should demonstrate a qPCR ratio $<2$, IHC $2+$ result samples should demonstrate ratios between 2.5 and 5.0, and IHC $3+$ result samples should demonstrate a qPCR ratio $>5$. This proposal is in concordance with biopsies and qPCR results obtained in this manuscript.

In this study, qPCR technique has been shown to be complementary to IHC analysis, similar to FISH; however, qPCR analysis is faster, less expensive and is an equally useful alternative methodology for patients.

\section{Acknowledgements}

We thank pathologist Dr Mario Knomura for giving us the opportunity to use archived tissue samples. Also to CONACyT for supporting the program of incorporation of scientists and technologists to the productive sector where we began this study in 2006.

\section{References}

1. Osborne C, Wilson P and Tripathy D: Oncogenes and tumor suppressor genes in breast cancer: potential diagnostic and therapeutic applications. Oncol 9: 361-377, 2004.

2. Ross JS, Fletcher JA, Bloom KJ, Linette GP, Stec J, Symmans WF, Pusztai L and Hortobagyi GN: Targeted therapy in breast cancer. Mol Cell Prot 3: 379-392, 2004.

3. Tsuda H: HER-2 (c-erbB-2) test update: present status and problems. Breast Cancer 13: 236-248, 2006.

4. Turbett GR, Barnett TC, Dillon ED and Sellner LN: Single tube protocol for the extraction of DNA or RNA from paraffin embedded tissues using a starch based adhesive. Biotech 20: 846-853, 1996.
5. Ausbel FM, Brent R, Kingston RE, Moore DD, Seidman JG, Smith JA and Struhl K: Short Protocols in Molecular Biology, 5th edition. John Wiley \& Sons, New York, p1512, 2002.

6. Königshoff M, Wilhelm J, Bohle RM, Pingoud A and Hahn M: HER-2/neu gene copy number quantified by real time PCR: comparison of gene amplification, heterozygosity and immunohistochemical status in breast cancer tissue. Clin Chem 49: 219-229, 2003.

7. Willmore-Payne C, Holden JA, Zhou H, Gupta D, Hirschowitz S, Wittwer CT and Layfield LJ: Evaluation of HER-2/neu gene status in osteosarcoma by fluorescence in situ hybridization and multiplex and monoplex polymerase chain reactions. Arch Pathol Lab Med 130: 691-698, 2006.

8. Lal P, Salazar PA, Ladanyi M and Chen B: Impact of polysomy 17 on HER-2/neu immunohistochemistry in breast carcinomas without HER-2/neu gene amplification. J Mol Diag 5: 155-159, 2003.

9. Benöhr P, Henkel V, Speer R, Vogel U, Sotlar K, Aydeniz B, Reiser A, Neubauer H, Tabiti K, Wallwiener D and Kurek R: Her-2/neu expression in breast cancer. A comparison of different diagnostic methods. Anticancer Res 25: 1895-1900, 2005.

10. Merkelbach-Bruse S, Wardelmann E, Behrens P, Losen I, Buettner R and Friedrichs N: Current diagnostic methods of HER-2/neu detection in breast cancer with regard to real-time PCR. Am J Surg Pathol 27: 1565-1570, 2003.

11. Kulka J, Tőkés AM, Kaposi-Novák P, Udvarhelyi N, Keller A, Lotz G and Schaff Z: Detection of HER-2/neu gene amplification in breast carcinomas using quantitative real time PCR: a comparison with immunohistochemical and FISH results. Pathol Oncol Res 12: 197-204, 2006.

12. Dobson L, Conway C, Hanley A, Johnson A, Costello S O'Grady A, Connolly Y, Magee H, O'Shea D, Jeffers M and Kay E: Image analysis as an adjunct to manual HER-2 immunohistochemical review: a diagnostic tool to standardize interpretation. Histophatol 57: 27-38, 2010.

13. Gjerdrum LM, Sorensen BS, Kjeldsen E, Sorensen FB, Nexo E and Hamilton-Dutoit S: Real time quantitative PCR of microdissected paraffin-embedded breast carcinoma. J Mol Diag 6: 42-51, 2004.

14. Lehmann U, Glöckner S, Kleeberger W, Feist H, von Wasielewski $\mathrm{R}$ and Kreipe H: Detection of gene amplification in archival breast cancer specimens by laser assisted microdissection and quantitative real time polymerase chain reaction. Am J Pathol 156: 1855-1864, 2000.

15. Millson A, Suli A, Hartung L, Kunitake S, Bennett A, Nordberg MCL, Hanna W, Wittwer CT, Seth A and Lyon E: Comparison of two quantitative polymerase chain reaction methods for detecting HER2/neu amplification. J Mol Diag 5: 184-190, 2003.

16. Owens MA, Horten BC and Da Silva MM: HER2 amplification ratios by fluorescence in situ hybridization and correlation with immunohistochemistry in a cohort of 6556 breast cancer tissues. Clin Breast Cancer 5: 63-69, 2004.

17. Tse C, Brault D, Gligorov J, Antoine M, Neumann R, Lotz JP and Capeau J: Evaluation of the quantitative analytical methods real time PCR for HER-2 gene quantification and ELISA of serum HER-2 protein and comparison with fluorescence in situ hybridization and immnunohistochemistry for determining HER-2 status in breast cancer patients. Clin Chem 51: 1093-1101, 2005.

18. Murphy SK, Magliocco AM and Demetrick DJ: Copy number analysis of c-erb-B2 (HER-2/neu) and topoisomerase II $\alpha$ genes in breast carcinoma by quantative real time polymerase chain reaction using hybridization probes and fluorescence in situ hybridization. Arch Pathol Lab Med 129: 39-46, 2005. 